Note

\title{
Intake of Iodine and Major Nutrients in an Area of Endemic Goitre
}

\author{
Purificacion Muros, M. Dolores Ruiz-Lopez, and M. Fatima OleA \\ Departamento de Nutricion y Bromatologia, \\ Facultad de Farmacia Universidad de Granada, \\ E-18071 Granada, Spain
}

(Received September 8, 1992)

\begin{abstract}
Summary We surveyed the diet of a group of inhabitants in a mountainous area where goitre was endemic. The amount of iodine supplied by the diet was determined by analyzing foods with gas chromatography with electron-capture detection. The mean daily intake of iodine per person was between 286.4 and $1,134.4 \mu \mathrm{g}$. These values are within acceptable ranges recommended by several authors. The dietary supplies of proteins, fats and carbohydrates were also all within the ranges recommended by the FAO/WHO. Although goitre was endemic in the area studied, no dietary deficiency in iodine supply was found in any of the families investigated. Thus the ultimate cause of the endemic will have to be sought in other etiologic factors.
\end{abstract}

Key Words endemic goitre, iodine, food, gas chromatography

In 1960 the World Health Organization published an extensive study of endemic goitre, which was said to affect approximately $5 \%$ of the world's population. More recently, in 1983 Matovinovic (1) estimated that of the approximately 300 million persons who suffer from goitre, 100 million live in industrialized areas.

Many theories have been proposed to explain the etiology of endemic goitre; however, only three are based on experimental evidence: nutritional iodine deficiency (2), the presence of goitrogenic substances in foods, and the quality of the drinking water (3).

In the Alpujarras region, located in the Penibetic Mountains in Spain, the prevalence of endemic goitre is high (13.4\%) (4). The nutritional habits of the inhabitants of this region have been studied, and iodine content in the most frequently consumed foods has been measured.

We surveyed the frequency of consumption of different foods, using a questionnaire that was specially designed to take into account the regional eating habits of the study population, and analyzed iodine content in different foods using gas chromatography with an electron-capture detector, according to the technique of Funazo et al. (5) with some modifications. 
Table 1. Geographical data of the Alpujarras region in southeastern Spain.

\begin{tabular}{lccc}
\hline Town & $\begin{array}{c}\text { Surface } \\
\left(\mathrm{km}^{2}\right)\end{array}$ & $\begin{array}{c}\text { Elevation } \\
(\mathrm{m})\end{array}$ & Inhabitants \\
\hline Castaras & 16.6 & 1,020 & 366 \\
Nieles & 10.2 & 999 & 20 \\
Juviles & 16.3 & 1,260 & 203 \\
\hline
\end{tabular}

Experimental. Apparatus: Halogen derivatives were analyzed with a Sigma 3B gas chromatograph equipped with an electron-capture detector and a Sigma 15 computerized recorder (both Perkin Elmer).

We used a stainless steel column $(2 \mathrm{~m} \times 2 \mathrm{~mm})$ packed with Poropack P (80/ 100 mesh), under the following conditions: injector temp., $200^{\circ} \mathrm{C}$; detector temp., $300^{\circ} \mathrm{C}$; oven temp., $130^{\circ} \mathrm{C} ; \mathrm{N}_{2}$ carrier gas flow rate, $24 \mathrm{ml} / \mathrm{min}$; auxiliary gas flow rate, $40 \mathrm{ml} / \mathrm{min}$.

Reagents: All reagents were analytical reagent grade except pentane, which was manufactured specifically for electron-capture detectors. All reagents were from Merck.

The stock solutions used were $10^{-2} \mathrm{M} \mathrm{ICH}_{3}$ and $10^{-2} \mathrm{M} \mathrm{IC}_{3} \mathrm{H}_{7}$ in pentane. From stock solutions, we prepared working solutions for the chromatographic method.

Nutritional questionnaire: The population studies was selected on the basis of the incidence of goitre and the number of inhabitants with the disease. All participants resided in isolated mountain villages (Table 1). The number of statistically representative families, $(n)$, was determined from the results of a previous questionnaire, according to the equation:

$$
n<\frac{N(1.96)^{2} S^{2}}{E^{2} N+(1.96)^{2} S^{2}},
$$

where $N$ is size of the population, $E$ is the mean error, $S$ is the variance and 1.96 is the factor used with $95 \%$ confidence limits. In all, 20 families were sampled: 10 in which no member had goiter, and 10 in which at least one member had the disease. The families ranged in size from two to seven members.

The food composition tables used to asses overall intakes of energy, protein, fats and carbohydrates were those published by Jiménez Cruz and Cervera Ral (6), which were computerized to facilitate data recording and management.

Iodine content in foods produced in the region studied was calculated directly from experimental data obtained in our laboratory.

Iodine content in foods: Iodine in foods was analyzed with the above mentioned technique adapted to the characteristics of the food samples.

The samples were mineralized as follows: Foods were first homogenized and dried, then $0.5 \mathrm{~g}$ was placed in a covered porcelain melting pot with $1 \mathrm{ml} \mathrm{ZnSO}_{4}$ solution and $2 \mathrm{ml} 1 \mathrm{~N} \mathrm{NaOH}$ solution, and ashed at $400-500^{\circ} \mathrm{C}$ for $90 \mathrm{~min}$. The 
product was allowed to cool, then $1 \mathrm{ml}$ distilled water and $1 \mathrm{ml} \mathrm{ZnSO}$ solution were added and ashing was repeated under the same condition as above for $90 \mathrm{~min}$ to obtain a white ash. When the melting pot had cooled, $20 \mathrm{ml}$ distilled water was added and the suspension was centrifuged for $15 \mathrm{~min}$ at 3,000 rpm. A 1-ml aliquot of the supernatant was methylated for chromatographic analysis of iodine content.

Methylation reaction: An aliquot of $1 \mathrm{ml}$ ash and $100 \mu \mathrm{SO}_{4}\left(\mathrm{CH}_{3}\right)_{2}$ were added to a capped test tube equipped with a reflux device, shaken and placed in a water bath at $70^{\circ} \mathrm{C}$ for $1 \mathrm{~h}$. The mixture was cooled and extracted with $1 \mathrm{ml}$ pentane, and $20 \mu \mathrm{l} 5 \times 10^{-5} \mathrm{M} \mathrm{IC}_{3} \mathrm{H}_{7}$ was added to the organic extract, which was shaken and injected $(1 \mu \mathrm{l})$ into the chromatograph apparatus under the conditons described above.

Results and Discussion. The data from the questionnaire confirmed the lack of variety in the diets consumed by subjects in the Alpujarras region of southern Spain. This may results from the poverty in the region, or from its relative isolation from large population centers.

The diet of the participants was characterized by the following features:

The only types of meat consumed frequently were pork and chicken. Other types of meat (beef, rabbit, etc.) were occasionally consumed by some families.

Fish was less common in the diet than meat, and was consumed once a week at the most. The lack of adequate facilities made frozen fish unaccessible to the population studied.

Table 2. Iodine content of foods commonly consumed in the Alpujarras region.

\begin{tabular}{lccc}
\hline Food & $\begin{array}{c}\text { Moisture } \\
(\%)\end{array}$ & $\begin{array}{r}\text { Edible proportion } \\
(\%)\end{array}$ & $\begin{array}{c}\text { Iodine } \\
(\mu \mathrm{g} / \mathrm{kg} \text { fresh matter })\end{array}$ \\
\hline Chard beet & 90.8 & 70 & 85.5 \\
Garlic & 63.8 & 76 & 246.6 \\
Eggplant & 92.4 & 85 & 111.7 \\
Pork & 71.2 & 72 & 392.5 \\
Chicken & 71.1 & 70 & $1,100.2$ \\
Onion & 89.1 & 85 & 392.5 \\
Cabbage & 87.8 & 75 & 682.8 \\
Cauliflower & 83.3 & 80 & 768.8 \\
Chick pea & 8.5 & 100 & 425.2 \\
Fig & 81.7 & 85 & 230.7 \\
Egg & 76.8 & 88 & 526.9 \\
Green bean & 89.9 & 91 & 386.6 \\
Goat milk & 90.5 & 100 & 83.6 \\
Apple & 84.0 & 84 & 200.0 \\
Bread & 24.2 & 100 & $1,384.8$ \\
Potato & 77.4 & 90 & $1,438.9$ \\
Green pepper & 92.8 & 81 & 151.2 \\
Fish & 76.9 & 70 & $1,681.7$ \\
Tomato & 93.5 & 94 & 109.8 \\
\hline
\end{tabular}


With few exceptions, the only milk consumed was goat milk. Those few subjects who reported eating cheese consumed types produced nonlocally.

No cereals were produced locally. Moderate amounts of rice and little pasta were consumed, whereas large amounts of wheat flour and wheat bread were present in the diet.

Olive oil was the only source of vegetable fat used; other types of vegetable or animal fat were practically absent from the diet.

Vegetables were consumed depending on seasonal availability. Potatoes, tomatoes, onions, garlic, and lettuce were available practically year-round, and were eaten in large amounts.

Quite a large variety of fruits were eaten, depending on seasonal availability. Only part of the fruit was grown locally. The diet included large amounts of cherries, plums, peaches, medlars, figs, apples, oranges, and grapes, all grown in Mediterranean regions.

Because coffee, infusions, honey, and a few other products were rarely consumed, these were not considered significant in the present study.

Although the diet was somewhat monotonous and poor in certain food groups that typify more industrialized populations, it can be described as a Mediterranean diet.

The analytical technique perfected in our laboratory was used to determine the

Table 3. Dietary supplies of major nutrients and $I_{2}$.

\begin{tabular}{crrrrr}
\hline $\begin{array}{c}\text { Family } \\
n\end{array}$ & $\begin{array}{c}\text { Energy } \\
(\mathrm{kJ} / \text { day })\end{array}$ & $\begin{array}{c}\text { Protein } \\
(\mathrm{g} / \text { day })\end{array}$ & $\begin{array}{c}\text { Fat } \\
(\mathrm{g} / \text { day })\end{array}$ & $\begin{array}{c}\text { Carbohydrates } \\
(\mathrm{g} / \text { day })\end{array}$ & $\begin{array}{c}\mathbf{I}_{2} \\
(\mu \mathrm{g} / \mathrm{day})\end{array}$ \\
\hline 1 & $10,955.3$ & 79.3 & 50.3 & 467.9 & 626.2 \\
2 & $9,598.9$ & 58.0 & 93.8 & 305.1 & 461.8 \\
3 & $15,359.8$ & 138.6 & 158.6 & 432.3 & $1,015.6$ \\
4 & $11,565.6$ & 98.5 & 76.7 & 422.3 & 715.9 \\
5 & $11,989.9$ & 111.2 & 98.5 & 345.4 & 797.7 \\
6 & $14,881.6$ & 120.9 & 184.7 & 367.6 & $1,071.6$ \\
7 & $5,360.4$ & 41.6 & 76.2 & 111.8 & 286.4 \\
8 & $9,316.3$ & 82.5 & 73.0 & 201.7 & 694.7 \\
9 & $11,793.4$ & 120.7 & 96.7 & 335.7 & 712.9 \\
10 & $10,101.3$ & 98.9 & 84.5 & 317.5 & 970.0 \\
11 & $12,127.8$ & 76.8 & 147.7 & 295.7 & 769.8 \\
12 & $7,437.0$ & 52.7 & 96.5 & 178.9 & 471.3 \\
13 & $10,112.6$ & 71.0 & 136.4 & 223.5 & 883.7 \\
14 & $12,291.7$ & 98.0 & 187.2 & 224.8 & 567.2 \\
15 & $12,595.5$ & 71.8 & 188.5 & 287.5 & 586.1 \\
16 & $18,180.0$ & 117.7 & 253.5 & 395.8 & $1,134.4$ \\
17 & $15,652.4$ & 118.2 & 171.7 & 421.1 & 852.1 \\
18 & $11,203.6$ & 71.2 & 117.4 & 323.6 & 705.4 \\
19 & $14,799.7$ & 108.9 & 186.4 & 374.7 & 840.7 \\
20 & $15,196.3$ & 98.8 & 193.8 & 352.1 & 733.0 \\
\hline
\end{tabular}


iodine content in the most foods most frequently consumed by the respondents to our questionnarie. The method was found to be suitably sensitive and reproducible for our purposes, as reported in an earlier study (7). The results are given in Table 2 .

The data from the questionaires were used to calculate mean daily levels of dietary iodide supplied per person, and mean supplies of major nutrients, e.g., proteins, fat and carbohydrates (Table 3 ).

The values for daily iodine requirements given in previously published studies vary widely from $100-150 \mu \mathrm{g} /$ day (8) to $1,000 \mu \mathrm{g} /$ day (9). In the USA, Werner and Ingbar (10) estimated mean daily intake to be $200-700 \mu \mathrm{g} /$ day. These authors also reported excess iodine intake in Japan, which on some islands reached $200 \mathrm{mg} /$ day, leading to thyroid alterations manifested as goitre.

In the Alpujarras region, mean iodine intake ranged from 286.4 to $1,071.4$ $\mu \mathrm{g} /$ day in families in which no member had goitre, and from 471.3 to $1,134.4$ /day in families in which at least one member had goitre. Our findings suggest that a deficiency in mean dietary iodine supplies is not the cause of endemic goitre in this region.

This study was supported by the Consejeria de Education y Ciencia of the Andalusian Regional Government through Project No. 0012-9. We thank Ms Karen Shashok for translating the original manuscript into English.

\section{REFERENCES}

1) Matovinovic, J. (1983): Endemic goiter and cretinism at the dawn of the third millenium. Annu. Rev. Nutr., 3, 341-412.

2) Stanbury, J. B., and Hetzel, B. (1980): Endemic Goiter and Endemic Cretinism. John Wiley \& Sons, Inc., New York.

3) Gaitan, E. (1980): Goitrogens in food and water. Annu. Rev. Nutr., 10, 21-39.

4) Vivanco, F., Palacios, J. M., Ramos, F., Busturia, M. A., and Muro, A. (1971): El bocio endemico en España. Rev. Clinica Esp., 123, 425-432.

5) Funazo, K., Tanaka, M., and Shono, T. (1981): Methylation of inorganic anions for gas chromatographic determination. J. Chromatogr., 211, 361-368.

6) Jiménez Cruz, A., and Cervera Ral, P. (1990): Tabla de Composición de Alimentos. Wander, Barcelona.

7) Muros Guadix, P. (1990): Analisis del Yodo. Prevalencia del bocio endémico en la Alpujarra granadina (Analysis of iodine. Prevalence of endemic goiter in the Alpujarras). PhD Thesis, Granada: Servicio de Publicaciones, Universidad de Granada.

8) Bender, A. E. (1977): Nutrición y Alimentos Dietéticos. Ed. Acribia, Zaragoza.

9) Hodges, R. E. (1981): Nutrición y Medicina Clínica. Ed. Interamericana. Madrid.

10) Werner, S. C., and Ingbar, S. H., Eds. (1978): The Thyroid: A Fundamental and Clinical Text. 4th ed., Harper \& Row, Hagerstown. 